\title{
Effect of Fed-batch Culturing on the Growth and Lipid Production of Chlorella vulgaris fo. tertia Applying pH-auxostat Acetic Acid and Predefined Exponential Glucose Feeding
}

\author{
Balázs József Nagy¹, Kristóf Nagy¹, Balázs Ivanics¹, Dániel Fózer², István Balogh³, Áron Németh* \\ ${ }^{1}$ Department of Applied Biotechnology and Food Science, Faculty of Chemical Technology and Biotechnology, Budapest \\ University of Technology and Economics, H-1111 Budapest, 6-8 Budafoki street, Hungary \\ 2 Department of Chemical and Environmental Process Engineering, Faculty of Chemical Technology and Biotechnology, Budapest \\ University of Technology and Economics, H-1111 Budapest, 8 Budafoki street, Hungary \\ ${ }^{3}$ Independent Researcher, H-1213 Budapest, 167 Hollandi street, Hungary \\ * Corresponding author, e-mail: naron@f-labor.mkt.bme.hu
}

Received: 16 August 2021, Accepted: 18 November 2021, Published online: 27 January 2022

\begin{abstract}
The techniques of heterotrophic microalgae cultivation used to be resulting in higher productivity and better yield than autotrophic culturing. Batch cultivation strategy is commonly used with high glucose concentration, but its potential is limited for biomass production at an industrial scale. Usually, the best productivity can obtain at lower glucose concentration. Moreover, other carbon sources can cause inhibition at higher concentrations. Therefore, the fed-batch cultivation strategy is an obvious choice, as it can maintain the optimal amount of carbon source can be maintained throughout the fermentation by automating the feeding. Such selfregulatory automation is provided by the $\mathrm{pH}$-auxostat addition of acetic acid, which was investigated in this study for Chlorella vulgaris fo. tertia. The $\mathrm{pH}$-auxostat fermentation was upscaled, then the feeding profile was modelled and transformed to another fermentation where glucose was used as a carbon source instead of acetic acid. Thus, the preferred carbon sources were compared under the same circumstances. It was found that the tested strain consumes dissolved oxygen very fast on both carbon substrates. It favored the acetic acid at high nitrogen and phosphorus concentrations. The final biomass concentration was $29.2 \mathrm{~g} / \mathrm{L}$ under pH-auxostat fed-batch strategy with acetic acid and $18.8 \mathrm{~g} / \mathrm{L}$ with glucose, respectively. The highest lipid content (393 mg/g) was measured from the biomass in the case of acetic acid. The fermentation settings need further optimization, but the results concluded that pH-auxostat acetic acid feeding has a great potential for scale-up of Chlorella fermentation.
\end{abstract}

Keywords

pH-auxostat, fed batch, acetic acid, heterotrophy, lipid content

\section{Introduction}

For decades, the development of technologies for algae cultivation and the processing of the resulting biomass has been focused mainly on the production of biofuels, as many microalgae species are capable of increased lipid production. When designing an algal cultivation system, the culturing conditions should be determined first, which can be autotrophic, mixotrophic, or heterotrophic depending on the circumstances and the carbon and energy sources. There is considerable interest in autotrophic culturing because the algae ponds and reactors use solar energy and capture a significant amount of atmospheric $\mathrm{CO}_{2}$ to grow the biomass, which could be a renewable raw material for the biofuel industry. However, the commercial implementation of microalgae to biofuel has several bottlenecks [1-3]. The integration of the technology into the waste remediation and applying heterotrophic culturing techniques could result in possible solutions [4]. In recent years, advances in algae technology have moved toward to the concept of biorefineries to extract high added-value algal components used by various industries ranging from pharmaceutical, nutraceutical, and cosmetic products. For example, omega-3-fatty acids (docosahexaenoic acid, DHA; eicosapentaenoic acid, EPA) and pigments (astaxanthin, C-phycocyanin, $\beta$-carotene, lutein), and to produce energy from the remained biomass derived by-products [5]. 
The way of culturing techniques determines the quality of the final product and the area of usage. Some algae can be cultured in outdoor systems with moderate stability because selective culturing circumstances, i.e., high salt concentration or nitrogen depletion, prevent foreign microorganisms and predators. Still, the annual productivity is highly dependent on the environment and climate. Several commercially interesting algae species are cultured under autotrophic outdoor conditions, as the production cost is lower than the mixotrophic or heterotrophic cultivation. The heterotrophic production of microalgae has higher final cell density and better growth rates compared to photoautotrophic production. The heterotrophy could host phytochemical production too [6]. Conversely, microalgae production under heterotrophic conditions can increase the production costs due to the need for an organic carbon source and the maintenance of the aseptic conditions [7].

The heterotrophic production of microalgae belonging to the Chlorella genus in most of the cases eliminates the requirement for light (which could cause several bottlenecks). It can reach higher final cell density as well as better growth rates compared to photoautotrophic production. Moreover, Chlorella sorokiniana mainly uses organic substrates rather than inorganic carbon when glucose or acetic acid is present [8].
The fed-batch fermentation technique is commonly used in the heterotrophic segment of microalgae cultivation. It makes the culturing easy for two-stage strategy and avoids the substrate inhibition [9], which occurs in many algae above at $20-50 \mathrm{~g} / \mathrm{L}$ concentrations of glucose or 5-10 g/L of acetate. Furthermore, it can provide higher biomass productivity than the batch culturing technique.

In several fed-batch Chlorella culturing studies, successful results were achieved in biomass or lipid yield and productivity by keeping the glucose concentration around $20 \mathrm{~g} / \mathrm{L}$ or lower [10-14]. The optimal concentration of acetate has founded at the level under $5 \mathrm{~g} / \mathrm{L}$ [15]. Chen and Johns found that acetate concentration above $0.4 \mathrm{~g} / \mathrm{L}$ has been progressively inhibited the growth of Chlamydomonas [16]. Higher tolerance was found in Haematococcus pluvialis culturing where up to $3 \mathrm{~g} / \mathrm{L}$ acetate showed inhibition in growth rate [17], and in the case of Chlorella sorokiniana, $14.4 \mathrm{~g} / \mathrm{L}$ acetate $(20 \mathrm{~g} / \mathrm{L}$ NaAc) caused complete inhibition of the growth [18]. The use of acetate salts or acetic acid as the carbon source in algal culturing is widely researched (Table 1) [19-25]. Still, in most cases, glucose resulted higher total biomass and productivity [26, 27]. Acetate has been worked effectively as an inducer of lipid production [28, 29] and also in terms of biomass yield [19]. At the same time it can be easily

Table 1 Fermentation results with acetate feed from different studies

\begin{tabular}{|c|c|c|c|c|c|c|c|}
\hline Strain & Reactor & Cultivation & Feeding & $\begin{array}{l}\text { Total DCW } \\
\qquad(\mathrm{g} / \mathrm{L})\end{array}$ & $\begin{array}{c}\text { DCW } \\
\text { Productivity } \\
(\mathrm{mg} / \mathrm{L} / \text { day) }\end{array}$ & $\begin{array}{l}\text { DCW } \\
\text { Yield } \\
(\mathrm{g} / \mathrm{g})\end{array}$ & Reference \\
\hline $\begin{array}{l}\text { Chlorella vulgaris } \\
\text { ESP-31 }\end{array}$ & $125 \mathrm{~m}^{2}$ open pond & $\begin{array}{l}\text { mixotrophic } \\
\text { mixotrophic }+ \\
\mathrm{CO}_{2} \text { fed-batch }\end{array}$ & $\begin{array}{c}0.05 \mathrm{M} \text { acetic acid addition at } \\
\text { night to regulate the } \mathrm{pH} \text { at } 6.5-7.5\end{array}$ & $\begin{array}{l}1.5410 \text { days } \\
2.3710 \text { days }\end{array}$ & $\begin{array}{l}154 \\
294\end{array}$ & $\begin{array}{c}\text { no } \\
\text { data }\end{array}$ & {$[20]$} \\
\hline $\begin{array}{l}\text { Chlorella vulgaris } \\
\text { ESP-31 }\end{array}$ & 1 Liter glass vessel & $\begin{array}{l}\text { mixotrophic } \\
\text { fed-batch }\end{array}$ & $\begin{array}{l}\mathrm{pH} \text { was controlled by } 5 \mathrm{~g} / \mathrm{L} \\
\text { acetic acid at } 7.5\end{array}$ & $\begin{array}{c}2.39 \\
10 \text { days }\end{array}$ & 242 & 0.68 & [19] \\
\hline $\begin{array}{l}\text { Crypthecodinium } \\
\text { cohnii }\end{array}$ & $\begin{array}{l}2 \mathrm{~L} \text { bioreactor with } \\
1 \mathrm{~L} \text { medium }\end{array}$ & $\begin{array}{c}\text { fed-batch } \\
\text { heterotrophic }\end{array}$ & $\begin{array}{l}50 \text { or } 100 \mathrm{w} / \mathrm{w} \% \text { acetic acid } \\
\text { feeding via } \mathrm{pH} \text { control at } 6.5\end{array}$ & $\begin{array}{c}51-61 \\
210 \text { hours }\end{array}$ & $243-290$ & 0.13 & {$[21]$} \\
\hline $\begin{array}{l}\text { Crypthecodinium } \\
\text { cohnii }\end{array}$ & $5 \mathrm{~L}$ fermenter & $\begin{array}{c}\text { fed-batch } \\
\text { heterotrophic }\end{array}$ & $\begin{array}{l}\text { The } \mathrm{pH} \text { was maintained at } 6.5 \text { by } \\
\text { the automatic addition of acetic } \\
\text { acid }(50 \% \mathrm{vol} / \mathrm{vol})\end{array}$ & $\begin{array}{c}45.5 \\
140 \text { hours }\end{array}$ & 325 & 0.21 & {$[22]$} \\
\hline $\begin{array}{l}\text { Chlorella } \\
\text { zofingiensis } \mathrm{G} 1\end{array}$ & $\begin{array}{l}40 \mathrm{~L} \text { vertical tubular } \\
\text { photobio-reactor }\end{array}$ & $\begin{array}{l}\text { mixotrophic } \\
\text { fed-batch }\end{array}$ & $\begin{array}{l}\mathrm{pH} \text { was adjusted to } 7.5 \text { four times } \\
\text { a day with } 99 \mathrm{w} / \mathrm{w} \% \text { acetic acid }\end{array}$ & $\begin{array}{c}\text { no data } \\
(1.25 \text { OD680) } \\
4 \text { days }\end{array}$ & no data & $\begin{array}{c}\text { no } \\
\text { data }\end{array}$ & {$[23]$} \\
\hline $\begin{array}{l}\text { Chlamydomonas } \\
\text { reinhardtii }\end{array}$ & $\begin{array}{l}1 \mathrm{~L} \text { bioreactor with } \\
800 \mathrm{~mL} \text { suspension }\end{array}$ & $\begin{array}{l}\text { mixotrophic } \\
\text { fed-batch }\end{array}$ & $\begin{array}{l}\mathrm{pH} \text { was controlled by } \sim 40 \mathrm{~m} / \mathrm{m} \% \\
\text { acetic acid and concentrated } \\
\text { nutrient solution at } 7.0\end{array}$ & $\begin{array}{c}23.68 \\
168 \text { hours }\end{array}$ & 141 & $\sim 0.44$ & {$[24]$} \\
\hline $\begin{array}{l}\text { Chlorella sp. FC2 } \\
\text { IITG }\end{array}$ & $\begin{array}{l}\text { 7.5 L bioreactors } \\
\text { (two in series) }\end{array}$ & $\begin{array}{l}\text { fed-batch/ } \\
\text { continuous }\end{array}$ & $\begin{array}{l}\text { Two-stage operation: } \\
\text { A: fed-batch with glucose and } \\
\text { nutrients feed } \\
\text { B: continuous addition of sodium- } \\
\text { acetate }(24 \mathrm{~g} / \mathrm{L} \text { in the broth })+\mathrm{pH} \\
\text { control with acetic acid at } 8\end{array}$ & $\begin{array}{c}160 / 300 \\
\text { hours }\end{array}$ & $\begin{array}{c}92700 \\
\text { biomass }\end{array}$ & $\begin{array}{c}\text { no } \\
\text { data }\end{array}$ & {$[25]$} \\
\hline
\end{tabular}


assimilated by the cells through the glyoxylate cycle or the tricarboxylic acid cycle (TCA) in the form of acetyl coenzyme A [30]. The automation of acetate substrate driven fed-batch processes is obvious, since the acetate uptake by the monocarboxylic/proton transporter [30] relates to proton consumption leading to alkalization of the fermentation broth. The rising $\mathrm{pH}$ triggers the $\mathrm{pH}$ control pumps so that the acetate is continuously available to the microalgae cells, and the increasing need is satisfied by an accelerating pump speed.

The objective of this study was to investigate the heterotrophic pH-auxostat fed-batch microalgae culturing technique and compare the growth parameters based on different carbon sources when the same feeding strategy is applied.

\section{Materials and methods}

\subsection{Microalgae and cultivation}

Chlorellra vulgaris fo. tertia Fott \& Novakova, 1969; (CCAP 211/11k) was obtained from Culture Collection of Algae and Protozoa (Scottish Association for Marine Science, Scotland, United Kingdom). This species is a variety of the Chlorella vulgaris M. Beijernick, 1890 genus. DNA/DNA hybridization results have shown a high degree of binding (97\% D) between the strains 211-11k and 21131, and $60 \%$ binding between them and strain 211-34. The latter two strains are species of Chlorella sorokiniana. This finding indicated that the tested strains are in the same homology group [31]. The Chlorella vulgaris fo. tertia was also referenced as strain 211-31 elsewhere [32] and also called it as Chlorella sorokiniana- - H-1985 and "K" strain Koch, 1985 [33]. The strain 211-11k was also designated as Chlorella sorokiniana Shihira et Krauss, 1965 [34]. Based on the current results, the strain 211-34 was named Chlorodium saccharophilum [35], then reclassified as Chlorella sp., because of its identical rDNA sequences and glycan pattern [36]. According to the complete sequence of 18S ribosomal RNA gene of strain 211-31 (GenBank KF673387) and the studies cited above, we concluded that the tested strain CCAP 211/11k should be a Chlorella sorokiniana 211-31. Our results are best compared with other Chlorella sorokiniana strains, rather than Chlorella sp. or C. vulgaris. The history of Chlorella taxonomy was thoroughly summarized in the study of Champenois et al. [37].

In our experiments the strain was maintained at $4{ }^{\circ} \mathrm{C}$ on Tamiya agar slant supplemented with glucose [38]. The medium contained $5 \mathrm{~g} / \mathrm{L}$ glucose-monohydrate, $5 \mathrm{~g} / \mathrm{L}$ $\mathrm{KNO}_{3}, 2.5 \mathrm{~g} / \mathrm{L} \mathrm{MgSO}_{4} .7 \mathrm{H}_{2} \mathrm{O}, 1.25 \mathrm{KH}_{2} \mathrm{PO}_{4}, 37 \mathrm{mg} / \mathrm{LEDTA}$, $9 \mathrm{mg} / \mathrm{L} \mathrm{FeSO}_{4} \cdot 7 \mathrm{H}_{2} \mathrm{O}, 20 \mathrm{~g} / \mathrm{L}$ agar and $0.08 \mathrm{ml}$ from micronutrient solution of $50 \mathrm{mg} / \mathrm{L} \quad \mathrm{Na}_{2} \mathrm{SiO}_{3} \cdot 9 \mathrm{H}_{2} \mathrm{O}$, $3100 \mathrm{mg} / \mathrm{L} \mathrm{H}_{3} \mathrm{BO}_{3}, 2230 \mathrm{mg} / \mathrm{L} \quad \mathrm{MnCl}_{2} \cdot 4 \mathrm{H}_{2} \mathrm{O}, 88 \mathrm{mg} / \mathrm{L}$ $\left(\mathrm{NH}_{4}\right)_{6} \mathrm{Mo}_{7} \mathrm{O}_{24} \cdot 4 \mathrm{H}_{2} \mathrm{O}, 119 \mathrm{mg} / \mathrm{L} \mathrm{KBr}, 83 \mathrm{mg} / \mathrm{L} \mathrm{KI}, 287 \mathrm{mg} / \mathrm{L}$ $\mathrm{ZnSO}_{4} \cdot 7 \mathrm{H}_{2} \mathrm{O}, 146 \mathrm{mg} / \mathrm{L} \quad \mathrm{Co}\left(\mathrm{NO}_{3}\right)_{2} \cdot 6 \mathrm{H}_{2} \mathrm{O}, 125 \mathrm{mg} / \mathrm{L}$ $\mathrm{CuSO}_{4} \cdot 5 \mathrm{H}_{2} \mathrm{O}, 474 \mathrm{mg} / \mathrm{L} \mathrm{Al}\left(\mathrm{SO}_{4}\right)_{3} \cdot 18 \mathrm{H}_{2} \mathrm{O}, 50 \mathrm{mg} / \mathrm{L} \mathrm{LiCl}$. The agar slants were incubated at $28{ }^{\circ} \mathrm{C}$ for 96 hours. The slants' cells were transferred using sterile loop into 250 $\mathrm{ml}$ Erlenmeyer flasks containing $100 \mathrm{ml}$ of similar Tamiya media (without agar) supplemented with $10 \mathrm{~g} / \mathrm{L}$ glucose-monohydrate. The inoculated Erlenmeyers incubated and shaked with $250 \mathrm{rpm}$ at $28^{\circ} \mathrm{C}$ in an incubator shaker (Excella E24, New Brunswick Sci. Co, USA) for 4 days at room light. All media were adjusted to $\mathrm{pH} 6.5$ before autoclaving at $121{ }^{\circ} \mathrm{C}$ for $20 \mathrm{~min}$ (ELV3870, Tuttnauer Europe BV, Netherlands). Before the inoculation step, the cell cultures' potential contamination was checked with Jenaval Microscope at 2000-fold magnification. The inoculation of the fermenter was designed to have a 1.0-2.6 g/L dry cellular weight (DCW). Thus, the biomass was collected from 3-4 flasks and then concentrated by centrifugation into $50 \mathrm{ml}$ volume as an inoculum.

\subsection{Fed-batch fermentations}

The lab-scale fed-batch fermentations were carried out with Biostat-Q (B.Braun Melsungen, Germany) 1 Liter glass bioreactor with $750 \mathrm{~mL}$ initial working volume: $700 \mathrm{~mL}$ Tamiya media and $50 \mathrm{~mL}$ concentrated biomass suspension. The composition of the fed media and other circumstances are summarized in Table 2. Acetate feeding (A/1) was also scaled up (A/2), glucose feeding (G/1) was further improved $(\mathrm{G} / 2)$.

In the case of acetic acid ( $\mathrm{pH}$-auxostat) fermentations, the $\mathrm{pH}$ level of the culture media was maintained at $\mathrm{pH}$ 7.0. This is called for substrate-driven $\mathrm{pH}$ control, so the carbon and nutrient sources' feed was regulated by the automatic $\mathrm{pH}$ control at the value of $\mathrm{pH}$ 7.0.

We intended to compare glucose and acetate as carbon sources in fed-batch fermentations. The carbon molar concentrations of the feeding media were set to equal $(120.1 \mathrm{~mol} \mathrm{C} / \mathrm{L})$ in each experiment to compare the effect of acetate and glucose as carbon sources. The recorded data of $\mathrm{pH}$-auxostat acetate feeding (Fig. 1(A)) was used to design the same feeding profile for further experiment with glucose feed G/1 (Fig. 2(A)). The glucose fedbatch was realized with a self-designed programable peristaltic pump built on Arduino chipset. The exponential growth function Eq. (1) was fit to the feed dataset of A/1 experiment (0-60 hours) in Wolfram Mathematica (v12). 
Table 2 Summary of the fed-batch fermentations

\begin{tabular}{|c|c|c|c|c|}
\hline & $\mathrm{A} / 1$ & $\mathrm{~A} / 2$ & $\mathrm{G} / 1$ & $\mathrm{G} / 2$ \\
\hline Strategy & $\mathrm{pH}$-auxostat & upscaled pH-auxostat & $\begin{array}{c}\text { programmed glucose } \\
\text { fed-batch based on } \mathrm{A} / 1 \\
\text { pH-auxostat feeding profile }\end{array}$ & $\begin{array}{l}\text { modified programmed } \\
\text { glucose fed-batch }\end{array}$ \\
\hline Initial volume & $0.750 \mathrm{~L}$ & $10 \mathrm{~L}$ & $0.750 \mathrm{~L}$ & $0.750 \mathrm{~L}$ \\
\hline Initial DCW $(\mathrm{g} / \mathrm{L})$ & $1.0 \mathrm{~g} / \mathrm{L}$ & $2.6 \mathrm{~g} / \mathrm{L}$ & $1.5 \mathrm{~g} / \mathrm{L}$ & $2.2 \mathrm{~g} / \mathrm{L}$ \\
\hline Fed medium & $\begin{array}{c}5 \mathrm{M} \text { acetic acid } \\
17.5 \mathrm{x} \text { Tamiya }\end{array}$ & $\begin{array}{c}5 \mathrm{M} \text { acetic acid } \\
17.5 \mathrm{x} \text { Tamiya }\end{array}$ & $\begin{array}{c}\text { 1.67 M glucose } \\
\text { 17.5x Tamiya }\end{array}$ & $\begin{array}{c}\text { 1.67 M glucose } \\
12.5 x \text { Tamiya }\end{array}$ \\
\hline Feed profile & $\mathrm{pH}$-controlled & $\mathrm{pH}$-controlled & exponential $(\mu=0.054 / \mathrm{h})$ & exponential $(\mu=0.028 / h)$ \\
\hline Impeller & $4 \mathrm{~cm}$ cross shaped magnetic & 3 pieces of $\varnothing 10 \mathrm{~cm}$ Rushton & $4 \mathrm{~cm}$ cross shaped magnetic & $4 \mathrm{~cm}$ cross shaped magnetic \\
\hline Aeration & $0.5-1 \mathrm{vvm}$ & $1 \mathrm{vvm}$ & $1 \mathrm{vvm}$ & $1 \mathrm{vvm}$ \\
\hline Gas mix $(\mathrm{O} 2 \%)$ & $0-100 \mathrm{v} / \mathrm{v} \%$ & not used & $0-50 \mathrm{v} / \mathrm{v} \%$ & $0-30 \mathrm{v} / \mathrm{v} \%$ \\
\hline $\mathrm{pH}$ & automatic & automatic & manual & manual \\
\hline
\end{tabular}

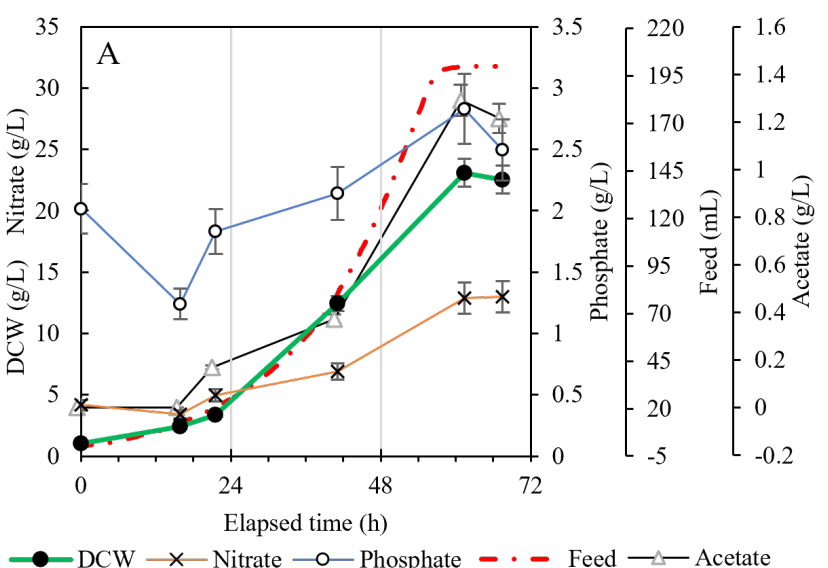

(a)

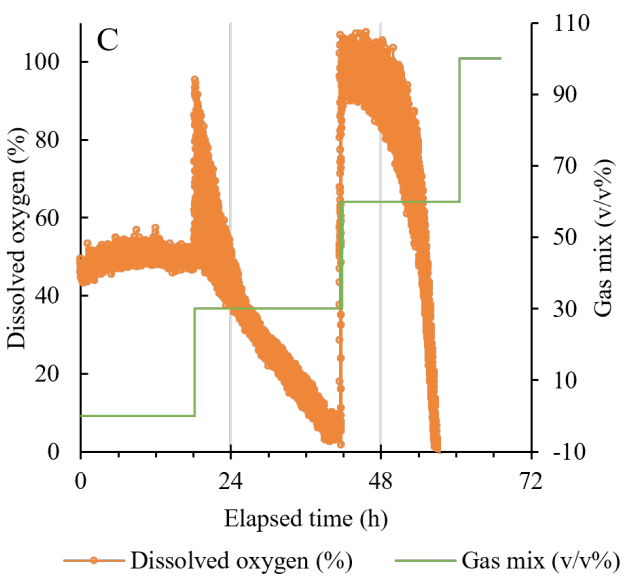

(c)

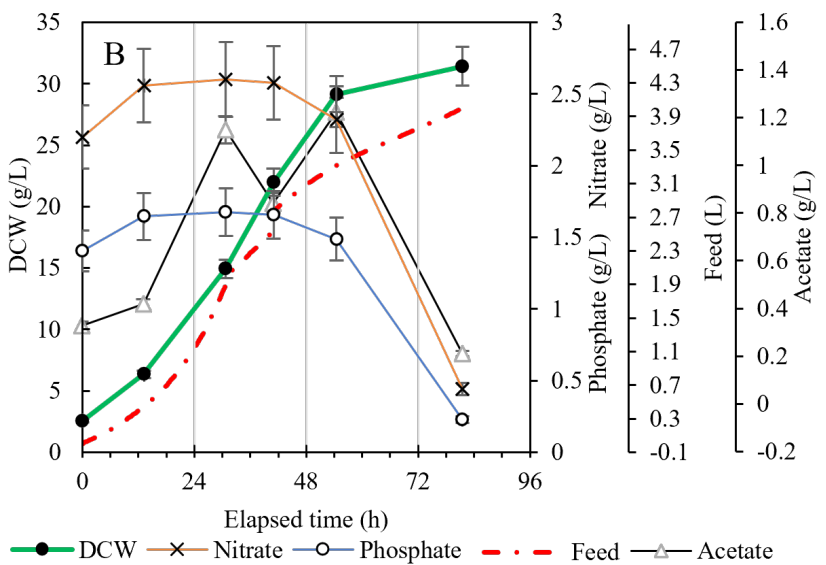

(b)

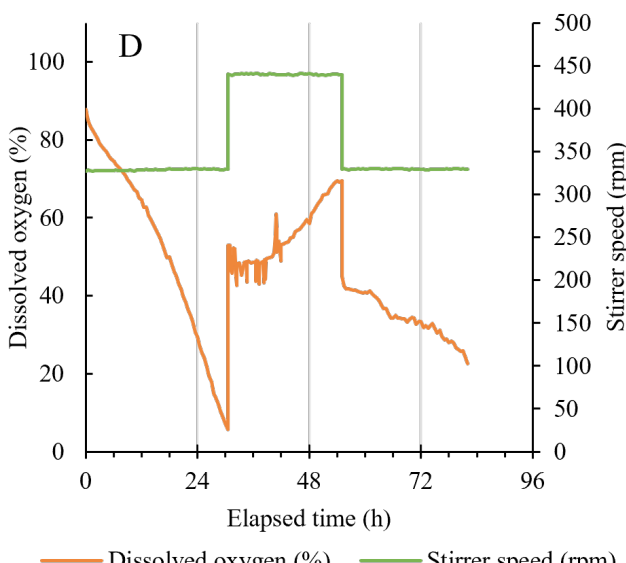

(d)

Fig. 1 pH-auxostat acetic acid fed-batch fermentations. Fermentation A/1 (a, c), ermentation A/2 (b, d)

The instrument could calculate the feeding rate according to the model. The algorithm gave commands every 2 seconds to the pump to add the calculated volume of the feeding medium to the fermenter. A similar fed-batch strategy was tested for Pichia pastoris [39], which was called to $\mu$-stat strategy.
$V(t)=V_{0} \times e^{\mu \times t}$

For such $\mathrm{pH}$-auxostat fermentations, the $\mathrm{pH}$ had to be adjusted manually only at the very beginning of the fermentations with $1 \mathrm{~N} \mathrm{NaOH}$ through one septum. No further manual $\mathrm{pH}$ adjustment was necessary. For all other 


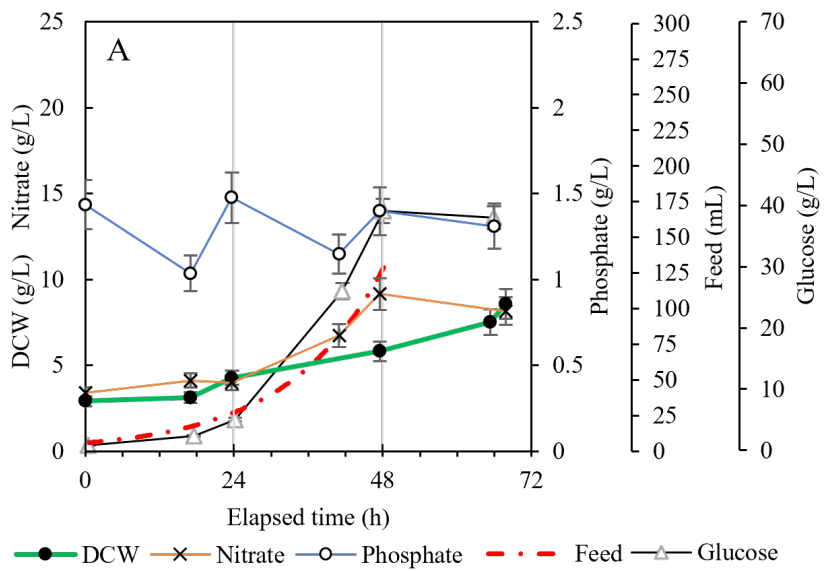

(a)

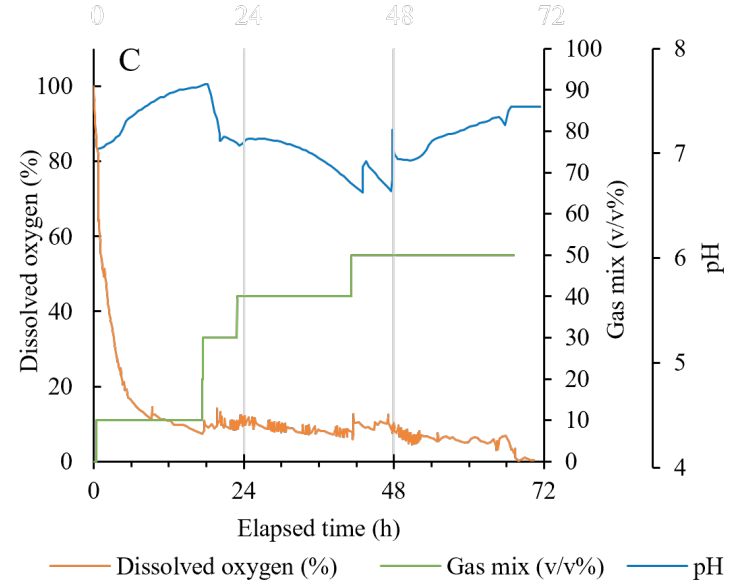

(c)

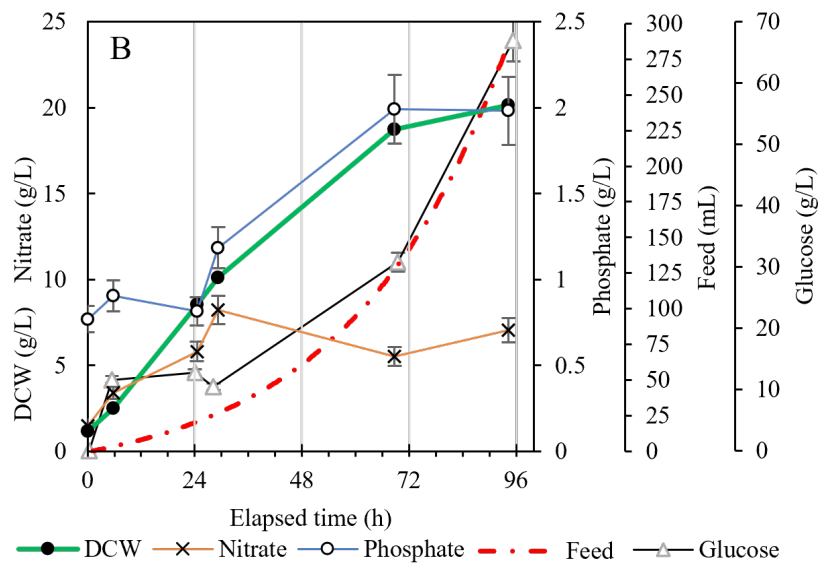

(b)

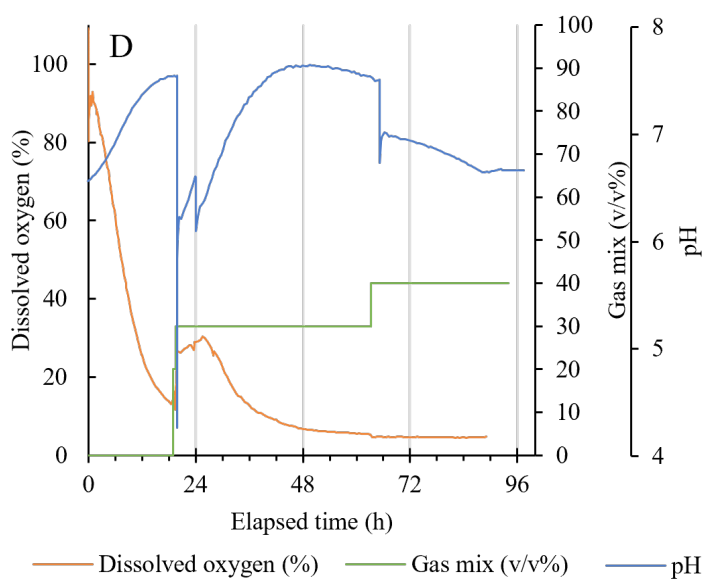

(d)

Fig. 2 Programmed exponential glucose fed-batch fermentations. Fermentation G/1 (a, c), Fermentation G/2 (b, d)

fermentations (G/1 and $\mathrm{G} / 2$ in Table 2), manual $\mathrm{pH}$ control was used. When the $\mathrm{pH}$ value reached 7.8-8.0, few milliliters of $0.1 \mathrm{~N} \mathrm{HCl}$ were added until the $\mathrm{pH}$ set to 6.5-7.0. Polypropylene glycol (2000) was used to prevent foaming $(1 \mathrm{~mL} / \mathrm{L})$. The cultures were maintained at $28{ }^{\circ} \mathrm{C}$. The stirring was maintained with a $4 \mathrm{~cm}$ length crossed shape magnetic bar, and the oxygen level was kept up to $20 \%$ of saturation with oxygen supplementation.

\subsection{Upscaling $\mathrm{pH}$-auxostat culturing}

The culture growing on acetic acid (A/1) was used as a seed fermentation for upscaling the culturing to 10 liters in Biostat-ED fermenter (A/2). The culture was not supplemented with additional oxygen, but more efficient Rushton impellers provided the sufficient dissolved oxygen concentration. The initial DCW was $2.6 \mathrm{~g} / \mathrm{L}$ in the upscaled fermenter $(\mathrm{A} / 2)$ after two $\mathrm{A} / 1$ fermentations were combined and transferred as $1100 \mathrm{~mL}$ inoculum. The $\mathrm{pH}$ control and prevention of foaming was solved in the same way as described at small-scale $\mathrm{pH}$-auxostat fermentation (A/1 in Table 2.).

\subsection{Analytical methods}

The cellular dry weight of the biomass was measured after washing by centrifugation at $4000 \mathrm{~g}$ for 10 minutes and replacing the supernatant with distilled water three times, then by drying the samples at $105^{\circ} \mathrm{C}$ to constant weight (Sartorius MA35). The optical density of the samples was also followed on $750 \mathrm{~nm}$ with a spectrophotometer. After calibration, the DCW could be calculated from the absorbance according to Eq. (2):

$$
D C W=0.5052 x-0.044 \text {. }
$$

The cell-free supernatants of the samples were kept on $-20{ }^{\circ} \mathrm{C}$ until further measurements. Sodium salicylate method [40] was used for determination of nitrate concentrations with spectrophotometer on $410 \mathrm{~nm}$. Phosphate concentration was detected on $690 \mathrm{~nm}$ after sample preparation by using the modified stannous chloride method [41].

The acetic acid and glucose concentrations were detected with isocratic Waters Breeze HPLC System used with BioRad Aminex HPX87H column at $65{ }^{\circ} \mathrm{C}$ with 
$5 \mathrm{mM} \mathrm{H} 2 \mathrm{SO} 4$ eluent and RI-detector at $40^{\circ} \mathrm{C}$. The injection volume was $10 \mu \mathrm{l}$ and the mobile phase volume rate was $0.5 \mathrm{~mL} / \mathrm{min}$.

\subsection{Lipid extraction and composition of fatty acids}

Total lipid extraction and lipid analysis were performed as described previously by Zhang et al. [42]. At the end of the fermentations directly $200 \mathrm{ml}$ samples were centrifuged and washed with distilled water three times, then dried at $105{ }^{\circ} \mathrm{C}$ overnight. One gram of cell pellets was transferred into a centrifuge tube, and $5 \mathrm{ml} 6 \mathrm{M} \mathrm{HCl}$ was added. The suspension was incubated for $1 \mathrm{~h}$ at $80^{\circ} \mathrm{C}$ in a water bath with a sealed cap. After that, the samples were cooled down quickly to room temperature, and the lipids were extracted by using $2 \mathrm{~mL}$-hexane and $0.75 \mathrm{~mL}$ absolute ethyl alcohol. The suspensions were mixed by vortex and centrifuged at $2400 \mathrm{~g}$ for $5 \mathrm{~min}$. The extraction process was repeated 3 times. The concentration of total lipids in DCW was determined gravimetrically after evaporating the solvents under oxygen-free nitrogen on a heating block maintained at $50^{\circ} \mathrm{C}$.

The lipid composition was determined with GC-MS after transmethylation of $100 \mathrm{mg}$ of lipids at $62{ }^{\circ} \mathrm{C}$ for one hour using $2 \mathrm{~mL} \mathrm{10 \%} \mathrm{(v/v)} \mathrm{methanolic} \mathrm{HCl}$ in sealed capped glass tubes. Subsequently, the fatty acid methyl esters (FAMEs) were dissolved in $2 \mathrm{~mL}$-hexane. The samples were shaken vigorously, then they were left on room temperature for an hour to complete phase separation.

GC-MS (Shimadzu GC/MS-QP2010 SE) analysis of FAMEs was conducted using an SGE BP5 (25 m $\times$ 0.25 micron) capillary column. The carrier gas was pure helium at a flow rate of $1.0 \mathrm{~mL} / \mathrm{min}$. The injector temperature was maintained at $250{ }^{\circ} \mathrm{C}$, and a volume of $1 \mu \mathrm{L}$ was injected using the split mode at a ratio of 5:1. The temperature of the column was increased from 150 to $220{ }^{\circ} \mathrm{C}$ at $10{ }^{\circ} \mathrm{C} / \mathrm{min}$ and further to $230^{\circ} \mathrm{C}$ at $2{ }^{\circ} \mathrm{C} / \mathrm{min}$. It was kept on $230{ }^{\circ} \mathrm{C}$ for $5 \mathrm{~min}$.

All fatty acids were identified by comparing them to the NIST mass spectral library. The mass spectroscopy instrument was operated at an ionization voltage of $70 \mathrm{ev}$, with a scan range of 35-450 amu.

\section{Results and discussion}

\section{1 pH-auxostat fermentations}

Acetic acid fed-batch fermentations were performed by adding the medium to the culture using a $\mathrm{pH}$-auxostat strategy on two scales (A/1 and A/2). The pH-auxostat strategy and using acetate as the carbon source in fed batch fermentations is a well-known setting. The cell culture from the 1-liter bioreactors (A/1) was transferred after 68 hours into a 10 -liter fermenter (A/2). The maximal values of the parameters at the end of the productive phases were summarized in Table 3. The upscaling resulted faster biomass growth which may have been caused by the more efficient stirring and oxygen transfer [43]. The end of the productive phases could be determined at 61 and 54 hours where the biomass concentrations were $23.1 \mathrm{~g} / \mathrm{L}$ and $29.2 \mathrm{~g} / \mathrm{L}$ (Fig. 1(A-B)). The pH-auxostat acetic acid fed fermentations resulted unique feed profile during our experiments (not all of them are presented in this article), where a special characteristic change in the shape of the curve (from exponent to linear) can be observed. This was found at 56 and 31 hours in the case of $\mathrm{A} / 1$ and $\mathrm{A} / 2$ fermentations.

The concentration of the main substrates showed an increasing tendency during the fermentation in the A/1 1 liter bioreactor (Fig. 1(A)). The final nitrate and phosphate concentrations were $12.99 \mathrm{~g} / \mathrm{L}$ and $2.49 \mathrm{~g} / \mathrm{L}$, which may suggest a lower optimal feed concertation for these substrates in the first scale. In the case of A/2 upscaled fermentation, the consumption of nitrate and phosphate were different because of the earlier change of feed profile (Fig. 1(B)). The feed bottle was emptied and replaced with fresh medium at 41 hours. The final concentrations of nitrate and phosphate was $0.44 \mathrm{~g} / \mathrm{L}, 0.23 \mathrm{~g} / \mathrm{L}$ respectively. Both were much lower than in the previous scale. Acetate concentrations tended to increase in both cases despite the $\mathrm{pH}$-auxostat strategy (1.29 $\mathrm{g} / \mathrm{L}$ and $1.22 \mathrm{~g} / \mathrm{L}$ maximum), which controlled the $\mathrm{pH}$ and also the carbon source concentration by definition, but an inhibition level was not reached in the biomass growth as it was not significantly present in the undissociated acid form [44]

The oxygen level was controlled by the addition of pure oxygen to the gas flow in the A/1 1-liter scale. Still, it was difficult to keep it on a sufficient level because of increased oxygen demand, even though the magnetic stirrer was kept at its maximum speed. The oxygen level was finally completely depleted around the $60^{\text {th }}$ hour, which may have caused a sudden slowdown in biomass growth (Fig. 1(C)). In the case of the A/2 10-liter fermenter, the dissolved oxygen level was decreased intensively in the first 30 hours. The stirrer speed of the Rushton turbine was increased by $100 \mathrm{rpm}$ which was sufficient, so the dissolved oxygen concentration recovered rapidly (Fig. 1(D)). Increasing the rate of agitation may have resulted in intense shear force that negatively affected the growth and the cellular metabolism. There was an inflection point of the growth curve, and the rate of auto- 
matic feeding was simultaneously decreased when the stirring speed was increased. Twenty-four hours later, stirring was decreased back to prevent shear stress. The dissolved oxygen concentration continued to decline, but biomass growth was already in a slowing phase. Worth mentioning that high oxygen demand was also determined in other acetic acid fed-batch experiments with Schizochytrium sp. [45].

The slowdown in biomass growth may also have been caused by the fact that the slower feed, which did not provide enough substrates for growth, so nitrate, phosphate, and acetate reached their critically minimal values and started to limit cell growth. Therefore, this feeding strategy would have more potential if the feeding profile could follow the growth curve exponentially until the end of the fermentation or other substrates (nitrate and phosphate) with higher concentrations might be regulated more better the cell growth rate.

The nitrate and phosphate concentrations of the feeding medium might be higher than it was needed, especially in the case of A/1 fermentation. Higher nitrate and phosphate tolerance was detected during the culturing.

Acetic acid was converted to biomass at a yield of $0.33 \mathrm{~g} / \mathrm{g}$ in both cases (A/1 and A/2 fermentations). In comparison, under mixotrophic condition, when $\mathrm{pH}$-stat strategy was applied higher yield $(0.68 \mathrm{~g} / \mathrm{g})$ was reached with culturing of Chlorella vulgaris ESP-31 [19]. Furthermore, Abiusi et al. [46] developed near carbon-neutral culturing conditions in mixotrophy when the $\mathrm{pH}$ was controlled by acetic acid addition without oxygen supply and other studies were described better yields too [44], but the final DCW and productivity (Table 1) are all comparable to our results (Table 3).

\subsection{Programmed glucose fed-batch}

The feed profile of the $\mathrm{A} / 1$ fermentation was modeled and imported into a programmable feed pump. As well as the
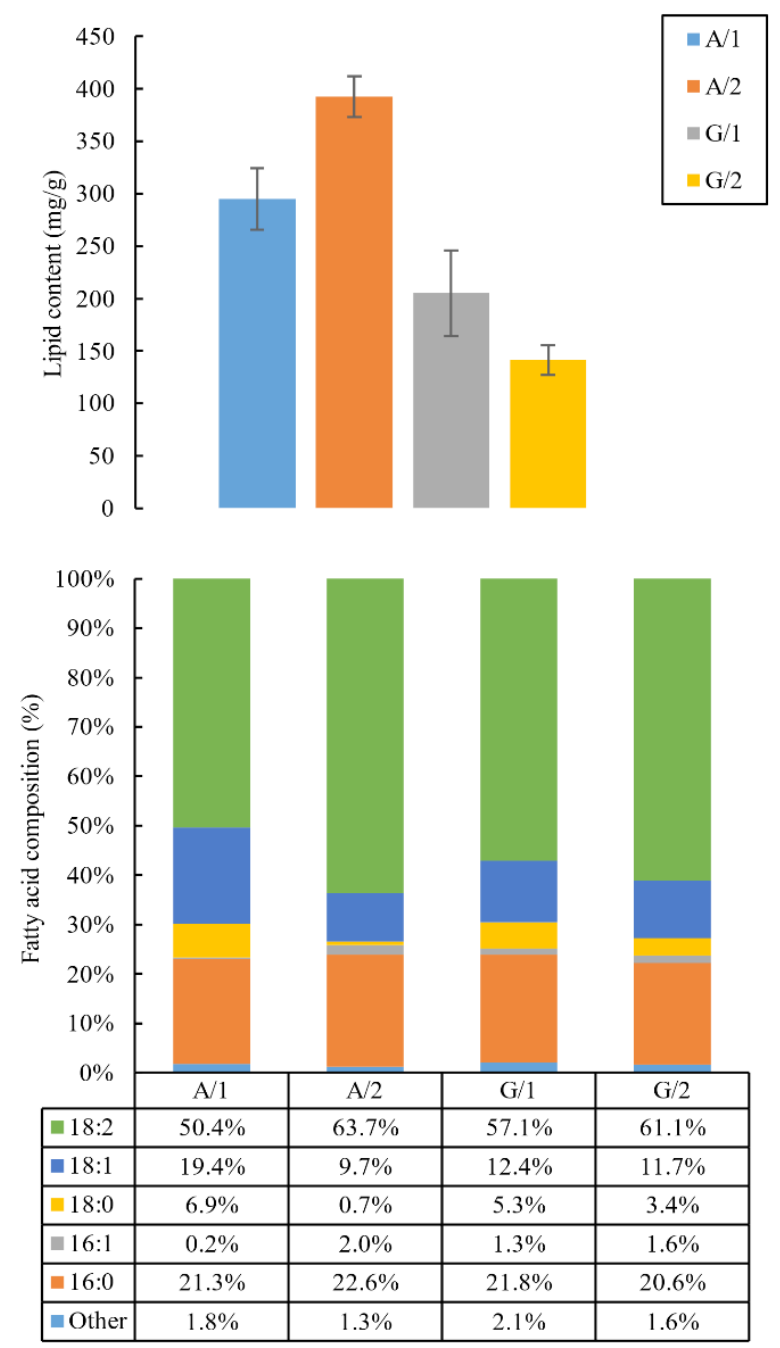

Fig. 3 Lipid content and fatty acid composition of the fed-batch fermentations via Chlorella vulgaris

same medium was used for the $\mathrm{pH}$-auxostat experiments, except the acetic acid was replaced by carbon equivalent concentration of glucose. We expected that glucose will result in more biomass in experiment $\mathrm{G} / 1$ based on some mass-cultivation results [47-49]. However, significant differences were measured.

Table 3 Summary of the results of pH-auxostat and glucose fed-batch fermentations at the end of the productive phases

\begin{tabular}{|c|c|c|c|c|}
\hline & $\mathrm{A} / 1$ & $\mathrm{~A} / 2$ & $\mathrm{G} / 1$ & $\mathrm{G} / 2$ \\
\hline Instrument & 1-Liter fermenter & 10-Liter fermenter & 1-Liter fermenter & 1-Liter fermenter \\
\hline End of the productive phase & 61.4 hours & 54.5 hours & $67.8 \mathrm{~h}$ & $69 \mathrm{~h}$ \\
\hline Biomass concentration & $23.1 \mathrm{~g} / \mathrm{L}$ & $29.2 \mathrm{~g} / \mathrm{L}$ & $8.6 \mathrm{~g} / \mathrm{L}$ & $18.8 \mathrm{~g} / \mathrm{L}$ \\
\hline New biomass & $20.2 \mathrm{~g}$ & $336.7 \mathrm{~g}$ & $3.0 \mathrm{~g}$ & $10.0 \mathrm{~g}$ \\
\hline Biomass productivity & $362 \mathrm{mg} / \mathrm{L} / \mathrm{h}$ & $497 \mathrm{mg} / \mathrm{L} / \mathrm{h}$ & $83 \mathrm{mg} / \mathrm{L} / \mathrm{h}$ & $254 \mathrm{mg} / \mathrm{L} / \mathrm{h}$ \\
\hline $\mathrm{Y}_{\mathrm{x} / \mathrm{S}}(\mathrm{g}$ biomass/g acetate $)$ & $0.33 \mathrm{~g} / \mathrm{g}$ & $0.33 \mathrm{~g} / \mathrm{g}$ & $0.21 \mathrm{~g} / \mathrm{g}$ & $0.49 \mathrm{~g} / \mathrm{g}$ \\
\hline$\mu \max$ & $0.062 / \mathrm{h}$ & $0.072 / \mathrm{h}$ & $0.031 / \mathrm{h}$ & $0.042 / \mathrm{h}$ \\
\hline Lipid content & $295 \mathrm{mg} / \mathrm{g}$ & $393 \mathrm{mg} / \mathrm{g}$ & $205 \mathrm{mg} / \mathrm{g}$ & $142 \mathrm{mg} / \mathrm{g}$ \\
\hline
\end{tabular}


Glucose and nitrate concentrations were rapidly increased in the first two days, so the feeding was stopped (49 h), and the fermentation continued for a further 18 hours, but the biomass growth was not intensive $(8.6 \mathrm{~g} / \mathrm{L}$ final DCW) (Fig. 2(A)). The insufficient growth was presumably caused by the fact that dissolved oxygen was reduced to a minimum level within a few hours and despite the increased pure oxygen introduction, the demand could not be compensated (Fig. 2(C)). The accumulated substrates could not have caused inhibition, as shown by the further increase of $\mathrm{pH}$ (Fig. 2(C)). Changes in $\mathrm{pH}$ can be used to infer metabolic function and biomass growth because glucose is taken up by a proton symporter [50].

Since in the glucose fed-batch fermentation, the $\mathrm{pH}$ was not controlled by the feeding, so the $\mathrm{pH}$ increased when the feeding was in balance with the biomass growth. This was seen in the first 17 hours of the fermentation (G/1). Then we needed to recalibrate the pump at the $23^{\text {rd }}$ hours because it started to add the media faster between 17-23 hours. Subsequently, the feeding was still faster than substrate depletion, so the culture medium was gradually acidified, which was compensated by manually adding $5 \mathrm{~N} \mathrm{NaOH}$. After we stopped the feeding, the metabolism went further, resulting in slow increase of the $\mathrm{pH}$ (Fig. 2(C)). The biomass productivity was very low $(83 \mathrm{mg} / \mathrm{L} / \mathrm{h})$ compared to the previous A/1 $(362 \mathrm{mg} / \mathrm{L} / \mathrm{h})$ and A/2 $(497 \mathrm{mg} / \mathrm{L} / \mathrm{h})$ experiments. These results are rather below those found in the literature using Chlorella strains [11, 51, 52].

By improving the first glucose fed-batch fermentation, we repeated the experiment with a nutrient solution having lower substrate concentration, and we halved the feeding rate as well. (Table 1./G/2). The phosphate and glucose concentrations also showed an upward trend with the new setup (Fig. 2(B)), but the biomass growth was significantly better (18.8 $\mathrm{g} / \mathrm{L} \mathrm{G} / 2$ and $8.6 \mathrm{~g} / \mathrm{L} \mathrm{G} / 1 \mathrm{DCW})$, and the productivity was $254 \mathrm{mg} / \mathrm{L} / \mathrm{h}$.

The oxygen demand was high like the previous G/1 experiment and the pure oxygen mixing could not provide a sufficient level of dissolved oxygen (Fig. 2(D)).

The cell metabolism caused a continuous $\mathrm{pH}$ increase during the first half of fermentation, which was compensated by the addition of $3 \mathrm{~N} \mathrm{HCl}$ around $\mathrm{pH} 7.0$ manually. In the second phase, it was seen that the exponential feeding rate had already exceeded the growth requirement, so the nutrient solution has slowly decreased the $\mathrm{pH}$ of the culture medium (Fig. 2(D)).

Glucose is the preferred carbon source in most experiments, as the culture also tolerates higher concentrations [48].
The techniques are known to develop a proper feeding strategy that results in good productivity and final biomass, but in the first experiments, substrate supplementation is primarily manual and time-dependent. Furthermore, a separate programmable feeding pump is needed for stepwise, pulsed, or exponential feeding [53].

\subsection{Lipid production}

The lipid production (Table 3 ) and the fatty acid composition of the four fermentations were compared (Fig. 3). $\mathrm{A} / 1$ and $\mathrm{A} / 2$ fermentations with acetic acid resulted in higher lipid content than those G/1 and G/2 fed with glucose. The upscaling resulted from $30 \%$ more lipid surplus than the smaller scale, so it finally reached $39 \mathrm{mg} / \mathrm{g}$ lipid content respectively.

The fatty acid compositions were similar in all experiments. The A/2 fermentation had 10\% more linoleic acid (18:2) than A/1, which has beneficial effects on health [54]. DHA and EPA were investigated in the samples, but the unsaturated fatty acids of 20-22 carbon atoms were less than $1 \%$.

The lipid production of Chlorella strains is usually indicated by stress factors. Therefore, starvation is applied during the culturing when glucose is the main carbon source. Nitrogen and phosphorous starvation combined with acetate supplementation increased biomass and lipid production with Chlamydomonas reinhardtii [55].

Acetic acid or acetate is also known as lipid inducer since the lipid content is usually higher than glucose-fed cultures [21, 28, 29].

\section{Conclusion}

In the present work, the acetic acid and glucose consumption were compared in fed-batch fermentations of Chlorella vulgaris fo. tertia. We found that the tested strain showed intensive growth when applying the $\mathrm{pH}$-auxostat feeding strategy, which resulted in better biomass productivity when a sufficient oxygen supply was provided in a fermenter. The culture consumed acetic acid much faster than glucose, resulting higher final biomass concentration and biomass productivity. The lipid content was also investigated during the fermentation trials. Acetate induced higher lipid production without nitrogen or phosphorus depletion. Neither condition produced omega-6 fatty acids (DHA, EPA), but the culture growth on acetate produced slightly higher omega-3 content.

The described fermentation experiments performed are first-step trials of our project. Despite the apparent 
necessity of further optimization, the results conclude that $\mathrm{pH}$-auxostat feeding has a great potential for scale-up Chlorella fermentation. A well-designed/optimized acetate-based fermentation technology can even lead to industrial manufacturing processes.

\section{References}

[1] Singh, A., Singh Nigam, P., Murphy, J. D. "Mechanism and challenges in commercialisation of algal biofuels", Bioresource Technology, 102(1), pp. 26-34, 2011.

https://doi.org/10.1016/j.biortech.2010.06.057

[2] Tang, Y., Rosenberg, J. N., Bohutskyi, P., Yu, G., Betenbaugh, M. J., Wang, F. "Microalgae as a Feedstock for Biofuel Precursors and Value-Added Products: Green Fuels and Golden Opportunities", BioResources, 11(1), pp. 2850-2885, 2016.

https://doi.org/10.15376/biores.11.1.Tang

[3] Sajjadi, B., Chen, W.-Y., Raman, A. A. A., Ibrahim, S. "Microalgae lipid and biomass for biofuel production: A comprehensive review on lipid enhancement strategies and their effects on fatty acid composition", Renewable and Sustainable Energy Reviews, 97, pp. 200-232, 2018.

https://doi.org/10.1016/j.rser.2018.07.050

[4] Venkata Mohan, S., Rohit, M. V., Chiranjeevi, P., Chandra, R., Navaneeth, B. "Heterotrophic microalgae cultivation to synergize biodiesel production with waste remediation: Progress and perspectives", Bioresource Technology, 184, pp. 169-178, 2015. https://doi.org/10.1016/j.biortech.2014.10.056

[5] Chew, K. W., Yap, J. Y., Show, P. L., Suan, N. H., Juan, J. C., Ling, T. C., ... Chang, J. S. "Microalgae biorefinery: High value products perspectives", Bioresource Technology, 229, pp. 53-62, 2017. https://doi.org/10.1016/j.biortech.2017.01.006

[6] Jareonsin, S., Pumas, C. "Advantages of Heterotrophic Microalgae as a Host for Phytochemicals Production", Frontiers In Bioengineering And Biotechnology, 9, Article number: 628597, 2021. https://doi.org/10.3389/fbioe.2021.628597

[7] Smetana, S., Sandmann, M., Rohn, S., Pleissner, D., Heinz, V. "Autotrophic and heterotrophic microalgae and cyanobacteria cultivation for food and feed: life cycle assessment", Bioresource Technology, 245(A), pp. 162-170, 2017. https://doi.org/10.1016/j.biortech.2017.08.113

[8] Huang, A., Sun, L., Wu, S., Liu, C., Zhao, P., Xie, X., Wang, G. "Utilization of glucose and acetate by Chlorella and the effect of multiple factors on cell composition", Journal of Applied Phycology, 29(1), pp. 23-33, 2017.

https://doi.org/10.1007/s10811-016-0920-6

[9] Wang, T., Tian, X., Liu, T., Wang, Z., Guan, W., Guo, M., ... Zhuang, Y. "A two-stage fed-batch heterotrophic culture of Chlorella protothecoides that combined nitrogen depletion with hyperosmotic stress strategy enhanced lipid yield and productivity", Process Biochemistry, 60, pp. 74-83, 2017. https://doi.org/10.1016/j.procbio.2017.05.027

[10] Ju, J.-H., Oh, B.-R., Ko, D.-J., Heo, S.-Y., Lee, J.-J., Kim, Y.-M., .. . Kim, C.-H. "Boosting productivity of heterotrophic microalgae by efficient control of the oxygen transfer coefficient using a microbubble sparger", Algal Research, 41, Article number: 101474, 2019. https://doi.org/10.1016/j.algal.2019.101474

\section{Acknowledgement}

The research reported in this paper and carried out at BME has been supported by the NRDI Fund (TKP2020 NC, Grant No. BME-NC) based on the charter of bolster issued by the NRDI Office under the auspices of the Ministry for Innovation and Technology.

[11] Wu, Z., Shi, X. "Optimization for high-density cultivation of heterotrophic Chlorella based on a hybrid neural network model", Letters in Applied Microbiology, 44(1), pp. 13-18, 2007. https://doi.org/10.1111/j.1472-765X.2006.02038.x

[12] Shi, X.-M., Chen, F. "High-Yield Production of Lutein by the Green Microalga Chlorella protothecoides in Heterotrophic FedBatch Culture", Biotechnology Progress, 18(4), pp. 723-727, 2002. https://doi.org/10.1021/bp0101987

[13] Liu, J., Sun, Z., Zhong, Y., Gerken, H., Huang, J., Chen, F. "Utilization of cane molasses towards cost-saving astaxanthin production by a Chlorella zofingiensis mutant", Journal of Applied Phycology, 25(5), pp. 1447-1456, 2013. https://doi.org/10.1007/s10811-013-9974-x

[14] Chen, Y.-H., Walker, T. H. "Biomass and lipid production of heterotrophic microalgae Chlorella protothecoides by using biodiesel-derived crude glycerol", Biotechnology Letters, 33(10), Article number: 1973, 2011.

https://doi.org/10.1007/s10529-011-0672-y

[15] Chen, C.Y., Ho, S.H., Liu, C.C., Chang, J.-S. "Enhancing lutein production with Chlorella sorokiniana $\mathrm{Mb}-1$ by optimizing acetate and nitrate concentrations under mixotrophic growth", Journal of the Taiwan Institute of Chemical Engineers, 79, pp. 88-96, 2017. https://doi.org/10.1016/j.jtice.2017.04.020

[16] Chen, F., Johns, M. R. "Substrate inhibition of Chlamydomonas reinhardtii by acetate in heterotrophic culture", Process Biochemistry, 29(4), pp. 245-252, 1994. https://doi.org/10.1016/0032-9592(94)80064-2

[17] Jeon, Y.-C., Cho, C.-W., Yun, Y.-S. "Combined effects of light intensity and acetate concentration on the growth of unicellular microalga Haematococcus pluvialis", Enzyme and Microbial Technology, 39(3), pp. 490-495, 2006. https://doi.org/10.1016\%2Fj.enzmictec.2005.12.021

[18] Qiao, H., Wang, G., Liu, K., Gu, W. "Short-term effects of acetate and microaerobic conditions on photosynthesis and respiration in Chlorella sorokiniana GXNN 01 (Chlorophyta)", Journal of Phycology, 48(4), pp. 992-1001, 2012. https://doi.org/10.1111/j.1529-8817.2012.01189.x

[19] Yeh, K. L., Chen, C. Y., Chang, J. S. "pH-stat photoheterotrophic cultivation of indigenous Chlorella vulgaris ESP-31 for biomass and lipid production using acetic acid as the carbon source", Biochemical Engineering Journal, 64, pp. 1-7, 2012. https://doi.org/10.1016/j.bej.2012.02.006

[20] Yu, Q., Wang, H., Li, X., Yin, Y., Qin, S., Ge, B. "Enhanced biomass and $\mathrm{CO} 2$ sequestration of Chlorella vulgaris using a new mixotrophic cultivation method", Process Biochemistry, 90, pp. 168-176, 2020. https://doi.org/10.1016/j.procbio.2019.11.022 
[21] De Swaaf, M. E., Sijtsma, L., Pronk, J. T. "High-cell-density fedbatch cultivation of the docosahexaenoic acid producing marine alga Crypthecodinium cohnii", Biotechnology and Bioengineering, 81(6), pp. 666-672, 2003. https://doi.org/10.1002/bit.10513

[22] Ratledge, C., Kanagachandran, K., Anderson, A. J., Grantham, D. J., Stephenson, J. C. "Production of docosahexaenoic acid by Crypthecodinium cohnii grown in a $\mathrm{pH}$-auxostat culture with acetic acid as principal carbon source", Lipids, 36(11), pp. 1241-1246, 2001. https://doi.org/10.1007/s11745-001-0838-x

[23] Huo, S., Wang, Z., Zhu, S., Shu, Q., Zhu, L., Qin, L., ... Dong, R. "Biomass Accumulation of Chlorella Zofingiensis G1 Cultures Grown Outdoors in Photobioreactors", Frontiers in Energy Research, 6, pp. 1-8, 2018.

https://doi.org/10.3389/fenrg.2018.00049

[24] Fields, F. J., Ostrand, J. T., Mayfield, S. P. "Fed-batch mixotrophic cultivation of Chlamydomonas reinhardtii for high-density cultures", Algal Research, 33, pp. 109-117, 2018.

https://doi.org/10.1016/j.algal.2018.05.006

[25] Palabhanvi, B., Muthuraj, M., Kumar, V., Mukherjee, M., Ahlawat, S., Das, D. "Continuous cultivation of lipid rich microalga Chlorella sp. FC2 IITG for improved biodiesel productivity via control variable optimization and substrate driven $\mathrm{pH}$ control", Bioresource Technology, 224, pp. 481-489, 2017. https://doi.org/10.1016/j.biortech.2016.11.020

[26] Heredia-Arroyo, T., Wei, W., Hu, B. "Oil Accumulation via Heterotrophic/Mixotrophic Chlorella protothecoides", Applied Biochemistry and Biotechnology, 162(7), pp. 1978-1995, 2010. https://doi.org/10.1007/s12010-010-8974-4

[27] Liang, Y., Sarkany, N., Cui, Y. "Biomass and lipid productivities of Chlorella vulgaris under autotrophic, heterotrophic and mixotrophic growth conditions", Biotechnology Letters, 31(7), pp. 1043-1049, 2009.

https://doi.org/10.1007/s10529-009-9975-7

[28] Palabhanvi, B., Muthuraj, M., Mukherjee, M., Kumar, V., Das, D. "Process engineering strategy for high cell density-lipid rich cultivation of Chlorella sp. FC2 IITG via model guided feeding recipe and substrate driven $\mathrm{pH}$ control", Algal Research, 16, pp. 317-329, 2016.

https://doi.org/10.1016\%2Fj.algal.2016.03.024

[29] Kumar, V., Muthuraj, M., Palabhanvi, B., Ghoshal, A. K., Das, D. "High cell density lipid rich cultivation of a novel microalgal isolate Chlorella sorokiniana FC6 IITG in a single-stage fed-batch mode under mixotrophic condition", Bioresource Technology, 170, pp. 115-124, 2014.

https://doi.org/10.1016/j.biortech.2014.07.066

[30] Perez-Garcia, O., Escalante, F. M. E., de-Bashan, L. E., Bashan, Y. "Heterotrophic cultures of microalgae: Metabolism and potential products", Water Research, 45(1), pp. 11-36, 2011. https://doi.org/10.1016/j.watres.2010.08.037

[31] Huss, V. A. R., Schwarzwälder, E., Kessler, E. "Deoxyribonucleic acid reassociation in the taxonomy of the genus Chlorella", Archives of Microbiology, 147(3), pp. 221-224, 1987. https://doi.org/10.1007/BF00463478
[32] Stuart, T. S., Gaffron, H. "The mechanism of hydrogen photoproduction by several algae: I. The effect of inhibitors of photophosphorylation", Planta, 106(2), pp. 91-100, 1972. https://doi.org/10.1007/BF00383989

[33] Punčochářová, M. "Culture Collection of Algae at the Department of Botany, Faculty of Natural Science, Charles University in Prague (CAUP)", Archiv für Protistenkunde, 138(2), pp. 143-158, 1990. https://doi.org/10.1016/S0003-9365(11)80157-0

[34] Kessler, E. "Comparative physiology, biochemistry, and the taxonomy of Chlorella (Chlorophyceae)", Plant Systematics and Evolution, 125(3), pp. 129-138, 1976. https://doi.org/10.1007/BF00986146

[35] Darienko, T., Gustavs, L., Mudimu, O., Menendez, C.R., Schumann, R., Karsten, U., ... Pröschold, T. "Chloroidium, a common terrestrial coccoid green alga previously assigned to Chlorella (Trebouxiophyceae, Chlorophyta)", European Journal of Phycology, 45(1), pp. 79-95, 2010. https://doi.org/10.1080/09670260903362820

[36] Mócsai, R., Figl, R., Sützl, L., Fluch, S., Altmann, F. "A first view on the unsuspected intragenus diversity of $\mathrm{N}$-glycans in Chlorella microalgae", the plant journal, 103(1), pp. 184-196, 2020. https:// doi.org/10.1111/tpj.14718

[37] Champenois, J., Marfaing, H., Pierre, R. "Review of the taxonomic revision of Chlorella and consequences for its food uses in Europe", Journal of Applied Phycology, 27(5), pp. 1845-1851, 2015. https://doi.org/10.1007/s10811-014-0431-2

[38] Tamiya, H., Iwamura, T., Shibata, K., Hase, E., Nihei, T. "Correlation between photosynthesis and light-independent metabolism in the growth of Chlorella", Biochimica et Biophysica Acta, 12(1-2), pp. 23-40, 1953. https://doi.org/10.1016/0006-3002(53)90120-6

[39] Liu, W.-C., Inwood, S., Gong, T., Sharma, A., Yu, L.-Y., Zhu, P. "Fed-batch high-cell-density fermentation strategies for Pichia pastoris growth and production", Critical Reviews in Biotechnology, 39(2), pp. 258-271, 2019. https://doi.org/10.1080/07388551.2018.1554620

[40] Monteiro, M. I. C., Ferreira, F. N., De Oliveira, N. M. M., Ávila, A. K. "Simplified version of the sodium salicylate method for analysis of nitrate in drinking waters", Analytica Chimica Acta, 477(1), pp. 125-129, 2003.

https://doi.org/10.1016/S0003-2670(02)01395-8

[41] Sletten, O., Bach, C. M. "Modified Stannous Chloride Reagent for Orthophosphate Determination", Journal AWWA, 53(8), pp. 10311033, 1961.

https://doi.org/10.1002/j.1551-8833.1961.tb00742.X

[42] Zhang, M., Wu, W., Guo, X., Weichen, Y., Qi, F., Jiang, X., Huang, J. "Mathematical modeling of fed-batch fermentation of Schizochytrium sp. FJU-512 growth and DHA production using a shift control strategy", 3 Biotech, 8(3), Article number: 162, 2018. https://doi.org/10.1007/s13205-018-1187-1

[43] Kim, H. S., Park, W.K., Lee, B., Seon, G., Suh, W. I., Moon, M., Chang, Y. K. "Optimization of heterotrophic cultivation of Chlorella sp. HS2 using screening, statistical assessment, and validation", Scientific Reports, 9(1), Article number: 19383, 2019. https://doi.org/10.1038/s41598-019-55854-9 
[44] Lacroux, J., Trably, E., Bernet, N., Steyer, J.-P., van Lis, R. "Mixotrophic growth of microalgae on volatile fatty acids is determined by their undissociated form", Algal Research, 47, Article number: 101870, 2020. https://doi.org/10.1016/j.algal.2020.101870

[45] Guo, D.-S., Ji, X.-J., Ren, L.-J., Li, G.-L., Yin, F.-W., Huang, H. "Development of a real-time bioprocess monitoring method for docosahexaenoic acid production by Schizochytrium sp.", Bioresource Technology, 216, pp. 422-427, 2016. https://doi.org/10.1016/j.biortech.2016.05.044

[46] Abiusi, F., Wijffels, R. H., Janssen, M. "Doubling of Microalgae Productivity by Oxygen Balanced Mixotrophy", ACS Sustainable Chemistry \& Engineering, 8(15), pp. 6065-6074, 2020. https://doi.org/10.1021/acssuschemeng.0c00990

[47] Doucha, J., Lívanský, K. "Production of high-density Chlorella culture grown in fermenters", Journal of Applied Phycology, 24(1), pp. 35-43, 2012. https://doi.org/10.1007/s10811-010-9643-2

[48] Barros, A., Pereira, H., Campos, J., Marques, A., Varela, J., Silva, J. "Heterotrophy as a tool to overcome the long and costly autotrophic scale-up process for large scale production of microalgae", Scientific Reports, 9(1), Article number: 13935, 2019. https://doi.org/10.1038/s41598-019-50206-Z

[49] Coelho, R. S., Vidotti, A. D. S., Reis, É. M., Franco, T. T. "High Cell Density Cultures of Microalgae under Fed-batch and Continuous Growth", Chemical Engineering transactions, 38, pp. 313-318, 2014. https://doi.org/10.3303/CET1438053

[50] Morales-Sánchez, D., Martinez-Rodriguez, O. A., Kyndt, J., Martinez, A. "Heterotrophic growth of microalgae: metabolic aspects", World Journal of Microbiology and Biotechnology, 31(1), pp. 1-9, 2014. https://doi.org/10.1007/s11274-014-1773-2
[51] Xiong, W., Li, X., Xiang, J., Wu, Q. "High-density fermentation of microalga Chlorella protothecoides in bioreactor for microbio-diesel production", Applied Microbiology and Biotechnology, 78(1), pp. 29-36, 2008. https://doi.org/10.1007/s00253-007-1285-1

[52] Shi, X.-M., Liu, H.-J., Zhang, X.-W., Chen, F. "Production of biomass and lutein by Chlorella protothecoides at various glucose concentrations in heterotrophic cultures", Process Biochemistry, 34(4), pp. 341-347, 1999.

https://doi.org/10.1016/S0032-9592(98)00101-0

[53] Bumbak, F., Cook, S., Zachleder, V., Hauser, S., Kovar, K. "Best practices in heterotrophic high-cell-density microalgal processes: achievements, potential and possible limitations", Applied Microbiology and Biotechnology, 91(1), pp. 31-46, 2011. https://doi.org/10.1007/s00253-011-3311-6

[54] Ramesh Kumar, B., Deviram, G., Mathimani, T., Duc, P. A., Pugazhendhi, A. "Microalgae as rich source of polyunsaturated fatty acids", Biocatalysis and Agricultural Biotechnology, 17, pp. $583-588,2019$ https://doi.org/10.1016/j.bcab.2019.01.017

[55] Yang, L., Chen, J., Qin, S., Zeng, M., Jiang, Y., Hu, L., ... Wang, J. "Growth and lipid accumulation by different nutrients in the microalga Chlamydomonas reinhardtii", Biotechnology for Biofuels, 11(1), Article number: 40, 2018. https://oi.org/10.1186/s13068-018-1041-z 